\title{
DETAILED PLANNING OF BEACH NOURISHMENT BASED ON MONITORING OF COASTLINE UNDULATIONS AND DUNE EROSION
}

\author{
H. Toxvig Madsen ${ }^{1}$, S. Bjerre Knudsen ${ }^{1}$ and P. Soerensen ${ }^{2}$
}

\begin{abstract}
The overall coastline management strategy for the central section of the Danish North Sea coast is to halt the process of coastal retreat and maintain a certain safety level against flooding. The sudden erosion of 10-25 $\mathrm{m}$ of a dune during a storm or a gale is thus a cause for concern. Such local dune erosion is often observed where an inward coastline undulation is situated off a section of the coast where the dune is not in equilibrium with the rest of the profile. During a storm this latent dune erosion is then released. By analysing the migration of coastline undulations and detecting the profiles with latent dune erosion the expectation is that the majority of large-scale dune erosion can be foreseen and avoided by adaptation of the nourishment programme.
\end{abstract}

Keywords: nourishment planning; coastline undulation; latent dune erosion

\section{INTRODUCTION}

In January 2005 the Danish North Sea coast was hit by a storm with mean wind velocities of up to $36 \mathrm{~m} / \mathrm{s}$. After the storm, the level of dune foot retreat was registered along the $110 \mathrm{~km}$ long central section of the coast. It appeared that the average level of dune foot retreat was $3.3 \mathrm{~m}$, but at certain points the dunes had retreated by up to $25 \mathrm{~m}$. Long stretches of coastline were also observed, however, in which the dunes had not retreated.

The water level during the storm has a return period of about 100 years. However, significant dune erosion is often observed at some local sections of the coastline after more moderate storms with lower water levels. It has been very difficult to explain why erosion is concentrated in these particular areas.

On a coastline where the general objective is to halt the process of coastal retreat and maintain a certain safety level against flooding, large-scale local dune erosion is obviously a cause for concern. It is also difficult to explain to the wider public how large scale dune erosion can take place on a coastline where erosion is supposed to be under control. Revetments have often been built to address these issues although nourishment is now generally considered to be the most appropriate solution.

Our hypothesis is that large-scale local dune erosion results from a combination of inward coastline undulation and latent or unreleased dune retreat. By monitoring these two phenomena continuously we expect to be able to predict which sites are likely to be at enhanced risk of large-scale dune erosion in the event of a storm. By using beach nourishment in advance the assumption is that dune erosion can be prevented or at least reduced in scale.

\section{DESCRIPTION OF THE COAST}

The following is a description of the central section of the Danish North Sea coast, see Fig. 1. The $110 \mathrm{~km}$ section is mainly a sandy coastline dominated by westerly winds and waves. On average there are about 75 days per year on which significant wave heights are above $2.5 \mathrm{~m}$. The tidal range is small, and the high water level within a 100 year return period is about $2.5 \mathrm{~m}$ to the north and $3.5 \mathrm{~m}$ to the south.

The area's first sea groynes were built in the 1880s and around 1960 about 100 were built along the northern part of the coast. Coastal surveying also began early. Already in 1874 the first sections of the coast were surveyed from dune top to a depth of $20 \mathrm{~m}$ in transects about $1 \mathrm{~km}$ apart and since the 1950s the entire coastal stretch has been surveyed every or every other year.

Annual retreat rates without nourishment have been calculated based on the profiles surveyed. Retreat rates are shown in Fig. 2, and it appears that they vary between 0 and $8 \mathrm{~m} /$ year, with the maximum values occurring where measurement locations are downstream of terminal groynes.

\footnotetext{
${ }^{1}$ Senior Coastal Engineer, Danish Coastal Authority, Box 100, DK-7620 Lemvig, Denmark, E-mail: htm@kyst.dk and sbk@kyst.dk

${ }^{2}$ Head of Coastal Research, Danish Coastal Authority, Box 100, DK-7620 Lemvig, Denmark, E-mail: pso@kyst.dk
} 


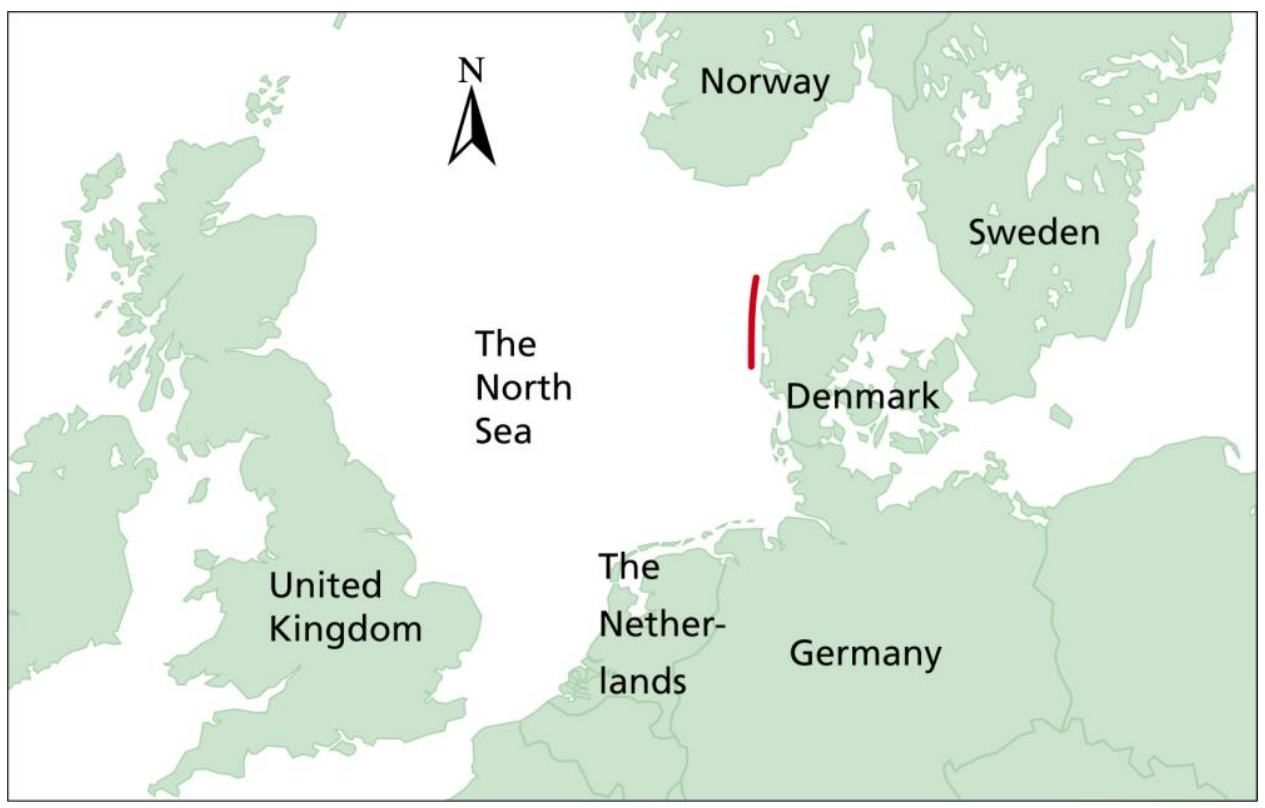

Figure 1. Location map

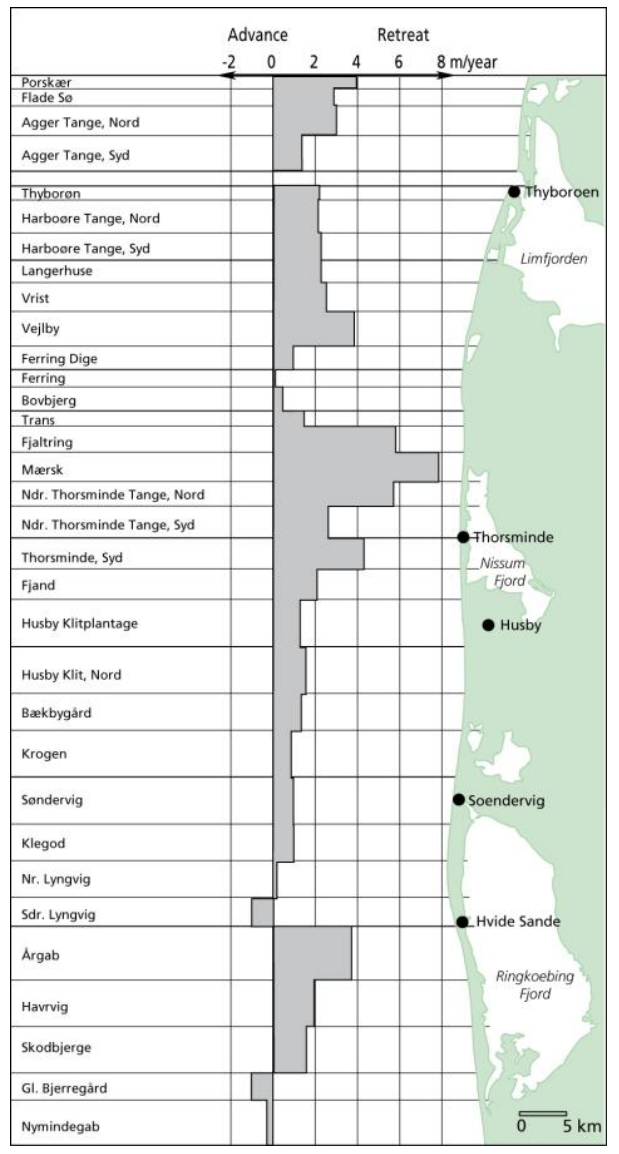

Figure 2. Annual coastal retreat rates without nourishment

The hinterland is characterized by three systems of narrow lowland spits, see Fig. 3. The rest of the hinterland is generally also low-lying, so there is some latent risk of flooding on this stretch of coastline. 
Figure 3. Low-lying areas in the hinterland

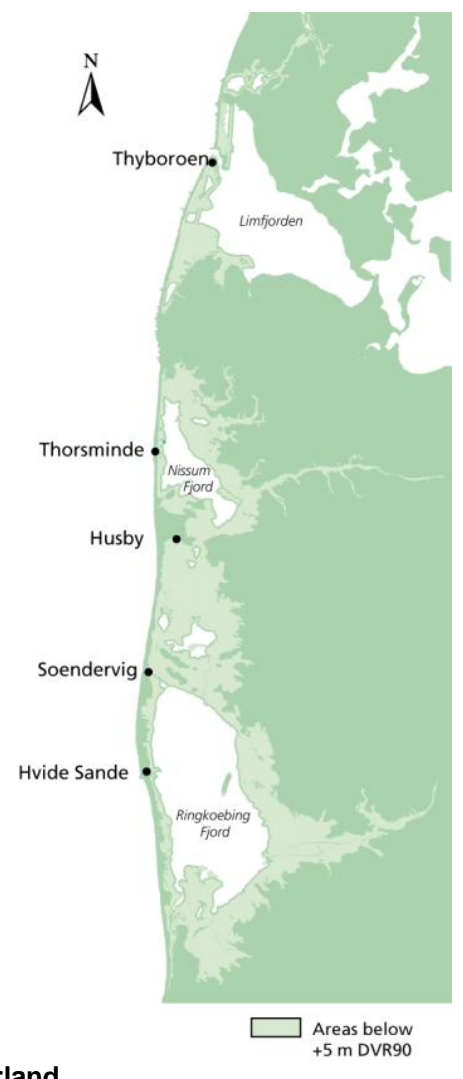

\section{THE COASTAL PROTECTION PROGRAMME}

After the sea groynes were built around 1960, coastal protection efforts on the central section of the Danish North Sea coast were limited to a few local measures. A storm in 1981 with a return period of 100 years changed this situation. The storm caused a significant coastal retreat and at a couple of locations the dune or the sand dike were breached, resulting in the inundation of low lying areas behind the coast. The damage caused by the storm revealed to the general public just how vulnerable the coastline is.

A decision was taken to increase coastal protection grants and a financed protection programme was agreed between the state, the county council and local municipalities. Since 1983, the coastal protection programme has been based on five year agreements between the three parties.

The strategy throughout this period has been:

- To stop or reduce coastal retreat where there is a risk to buildings and infrastructure.

- To maintain the safety level of dunes and sand dikes in order to avoid inundation of the low hinterland.

Initially the implementation of this strategy was based on coastal protection structures. About $25 \mathrm{~km}$ of concrete block revetment was built in areas where halting the dune foot retreat was a matter of urgency because of the proximity of houses or infrastructure or because the high water barrier was too narrow. A further 130 low breakwaters were constructed just beyond the coastline in order to protect the small quantities of nourishment sand on the beach in the 1980s.

Gradually confidence in sand nourishment as an effective coastal protection measure increased. By the end of the 80s annual nourishment volumes passed 1 mill. $\mathrm{m}^{3}$, and since the mid 90s 3 mill. $\mathrm{m}^{3} /$ year have been used.

Initially, nourishment measures consisted of beach nourishment and as late as the 90s most of the nourishment sand was pumped up on the beach. At that time, The Danish Coastal Authority took part in an EU-supported full-scale nourishment project called Nourtec, see Laustrup et al. 1997. The study compared beach and shoreface nourishment and based on its results it was decided that one third of the total nourishment volume should be placed at the shoreface. 
After a further full-scale shoreface nourishment test carried out by The Coastal Authority, the shoreface share was increased again. Since 2000, $60 \%$ of the nourishment on the central section of the Danish North Sea coast has been shoreface nourishment.

The coastal protection programme for the present agreement period 2009-13 is governed by the coastal retreat objective shown in Fig. 4. As can be seen, the object is to prevent the dunes retreating on the main part of the stretch. To the south a reduction of the retreat rate is sufficient. On some sections no retreat target has been set, either because natural retreat rates are very low or because there are no buildings or infrastructure close to the beach. These targets can be met with annual nourishment volumes of $2.3 \mathrm{mill} . \mathrm{m}^{3} /$ year.

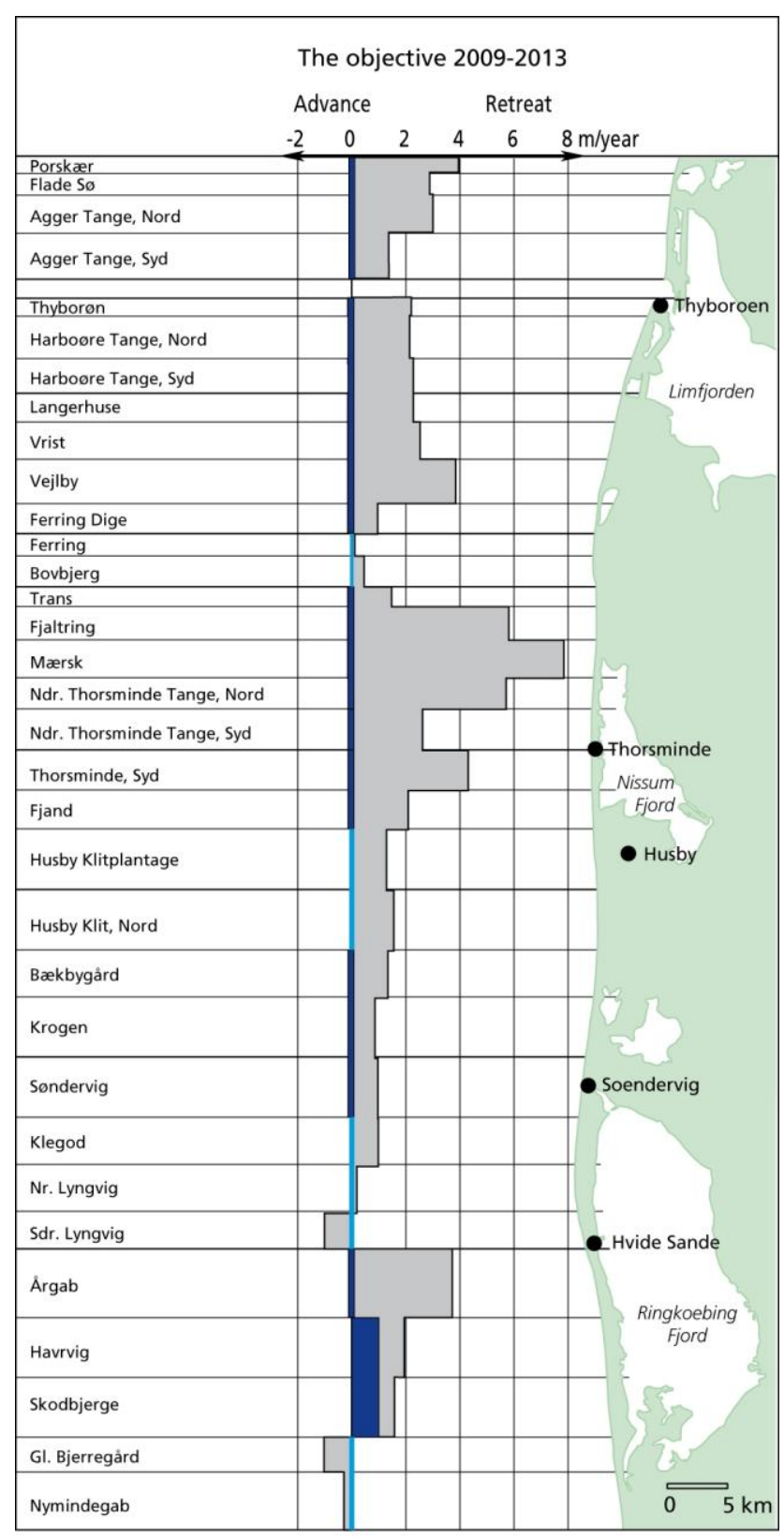

Annual retreat without nourishment

Objective for max annual coastal retreat

- No objective

Figure 4. The coastal retreat objective for the period 2009-13 
In addition to reducing coastal retreat rates, a further objective is to maintain inundation protection at acceptable levels. The safety level for the high water barrier is normally 100 years, meaning that the dune or sand dike should be able to withstand a storm with a 100-year water level return period. At Thyboroen the safety level is 1,000 years because the town would be isolated in the event that the high water barrier to the south of the town was breached.

A 100 year safety level is achieved when the width of the dune or sand dike exceeds $40 \mathrm{~m}$. This width criterion is based on an analysis of historical data for dune erosion. The analysis indicates that a storm with a 100 year water level can cause dune erosion of $30 \mathrm{~m}$. With the addition of a $10 \mathrm{~m}$ safety buffer a $40 \mathrm{~m}$ wide high water barrier is required.

The historical dune erosion data shows that even moderate storms and water levels can cause considerable dune erosion. It seems generally to be the case that levels of dune erosion are very local, and that in some areas erosion occurs on a scale that is much greater than would be expected.

Unforeseen extensive dune erosion is clearly a threat to the high water barrier. Furthermore, incidents of such erosion are difficult to explain to the general public.

In the following two cases the causes of extensive local dune erosion are analysed.

\section{SOENDERVIG}

\section{Introduction}

Soendervig is a holiday resort located $15 \mathrm{~km}$ north of Hvide Sande, see Fig. 2. The dunes here are 12-14 $\mathrm{m}$ high and there are a number of large holiday cottages situated close to the cliff.

The natural coastal retreat rate is $1.0 \mathrm{~m} / \mathrm{year}$ which is low compared to the rest of the stretch. During a storm in January 2005 about $25 \mathrm{~m}$ of the dune was removed by the sea leaving a number of holiday cottages amongst the dunes at high risk of sliding down onto the beach in the next storm, see Fig. 5.

The storm's water level had a return period of about 100 years. Although it was an extreme storm many sections of the $110 \mathrm{~km}$ coastline showed no signs of dune erosion. The average level of dune retreat was $3.3 \mathrm{~m}$, so the $25 \mathrm{~m}$ at Soendervig was extraordinary when compared to the rest of the stretch.

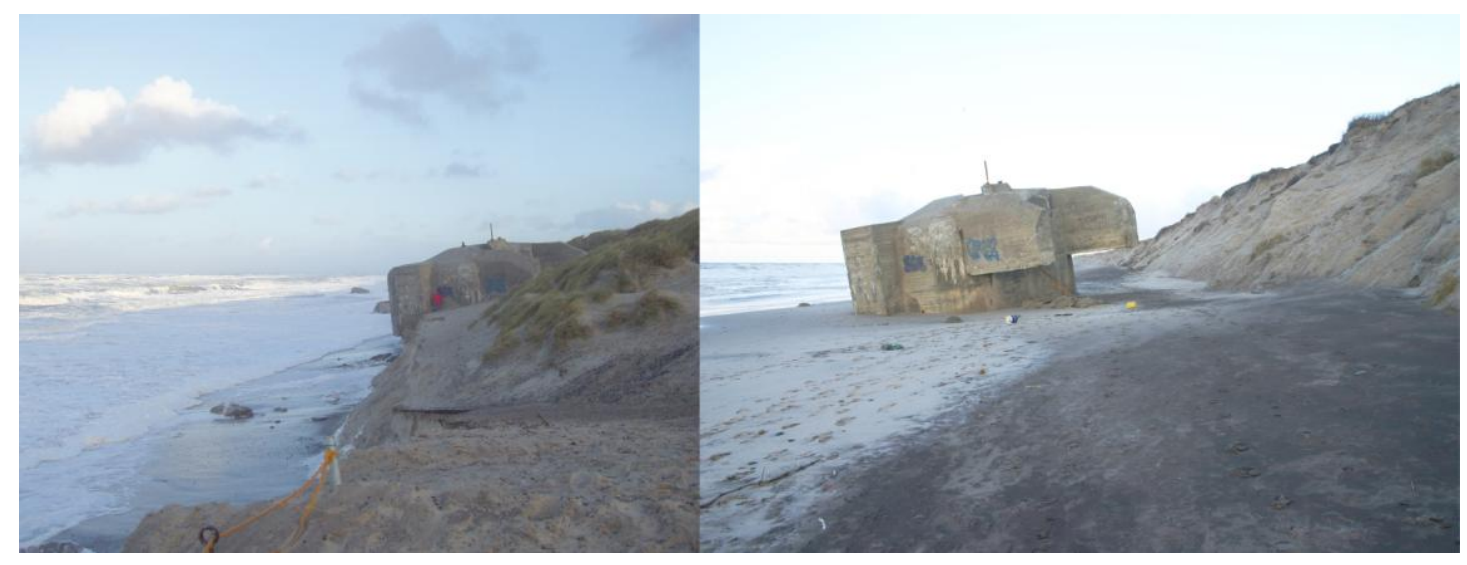

Figure 5. The dune foot before and after the storm at Soendervig

\section{Analysis of the inward coastline undulations}

Satellite photos dating back to 1998 of the stretch north of Soendervig are available and have been analysed. Some of the most recent pre-2005 photos are shown in Fig. 6 . The arrow indicates the position of the inward coastline undulation. In the analysis a much larger scale image was used, making it much easier to detect the undulations. 


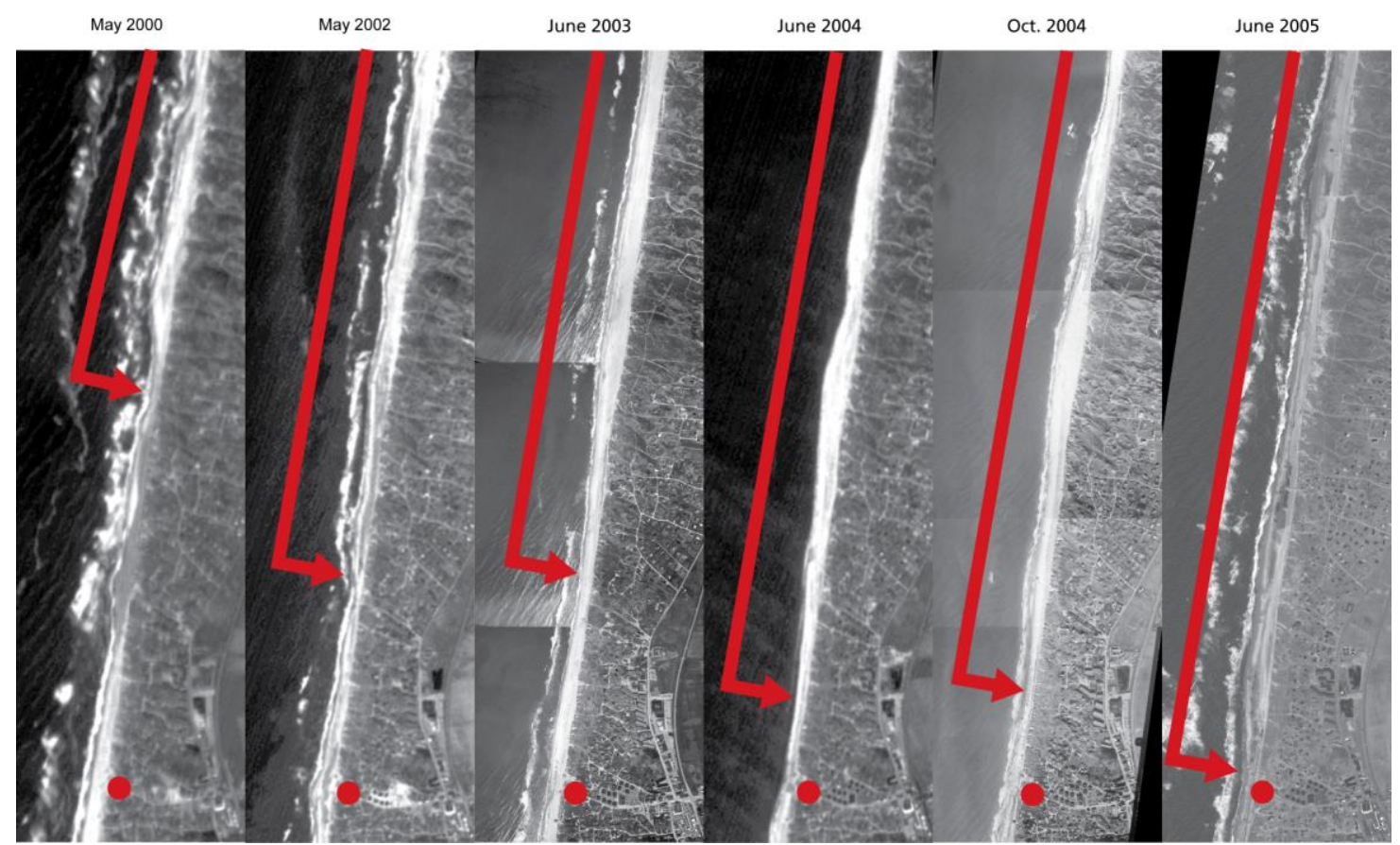

Figure 6. Satellite photos showing the migration of an inward coastline undulation north of Soendervig

It appears that the inward coastline undulation migrates to the south which is also the direction of net longshore drift. The undulation's migration velocity is about $400 \mathrm{~m} / \mathrm{year}$ and in January 2005 when the storm hit the coast the inward undulation was located just outside Soendervig.

\section{Analysis of rates of dune retreat in the years before the storm}

On this stretch of coastline transects that are about $1 \mathrm{~km}$ apart have been surveyed since 1957. Dune foot and coastline retreat rates for the transect located just outside Soendervig are shown in Fig. 7. These show that the coastline retreats at a gentle rate of about $1.4 \mathrm{~m} / \mathrm{year}$, and this is also true of the profile beyond the coastline. The dune foot has behaved quite differently, however. Since 1988, the dune foot has been stable and has even advanced as a result of aeolian transport. Thus the dune's retreat was delayed and instability or latent dune erosion came into play during the storm as a result of the high water levels and waves experienced.

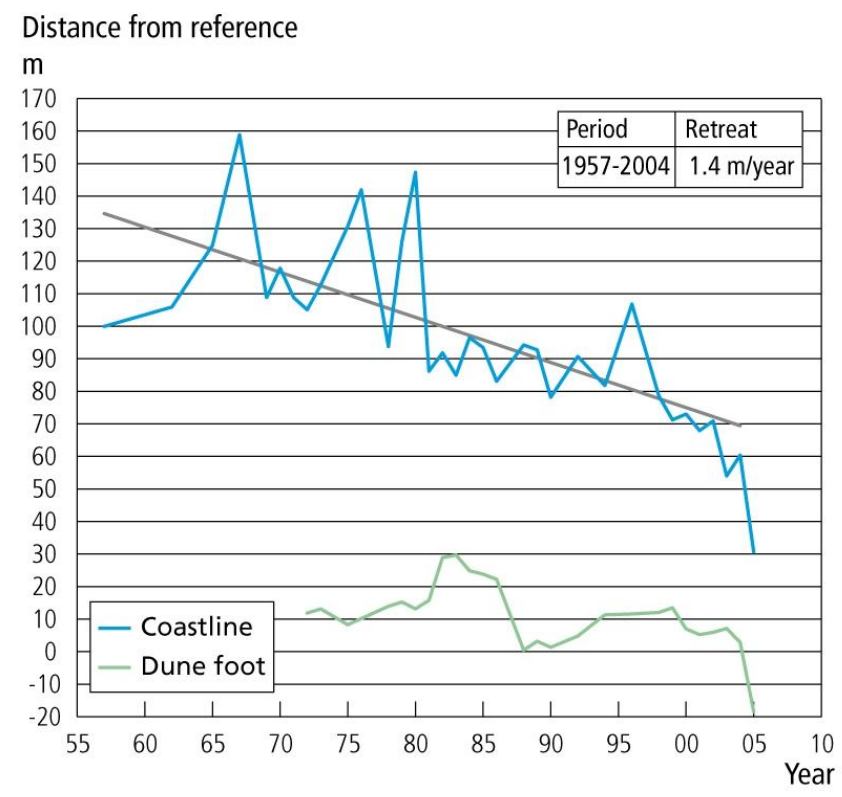

Figure 7. Coastline and dune foot retreat at Soendervig since 1957 


\section{Results}

Analysis of the Soendervig case indicates that extreme dune erosion can result from a combination of an inward coastline undulation located just outside the site and a dune with high levels of latent erosion accumulated over about 15 years.

It follows from this that analysis of both the migration of the coastline undulation and the dune retreat carried out 2-3 years before the storm would have made it clear that there was a high risk of extreme dune erosion in the next storm.

\section{HUSBY}

\section{Introduction}

Husby is located $20 \mathrm{~km}$ north of Soendervig, see Fig. 2. No coastal protection measures have ever been implemented at this site. This makes the site a suitable reference point for analysis of the rest of the central North Sea coast as any data collected is free from the influence of structures and nourishment sand. A $3 \mathrm{~km}$ long stretch has been monitored in detail since 1999.

Along the Husby stretch surveys have been carried out in transects $200 \mathrm{~m}$ apart. Profiles were surveyed from dune top to about the $14 \mathrm{~m}$ depth contour, and 3-4 surveys were carried out a year.

During the period covered by the Husby survey data there have been three significant storms including the 100 year storm of January 2005 analysed in the Soendervig case. In addition, the area experienced a 15 year storm in January 2000 and a 9 year storm in January 2002. In the Husby case the location of the inward coastline undulation and the rates of dune foot retreat during these three storms have been analysed.

\section{Analysis of inward coastline undulations}

Satellite photos are also available for the Husby stretch throughout the entire monitoring period. The position of inward coastline undulations was determined both on the basis of the satellite photo data and the coloured bathymetries. At the bathymetries the bars are also visible, making the undulations easier to detect, see Knudsen et al. 2006. An example is provided in Fig. 8.

This method was used to determine the position of inward coastline undulations throughout the period under analysis and thus covers all of the three storms. It should be noted that this analysis was carried out in 2005 and published in 2007, and so has not been influenced by more recent detailed dune retreat analysis.

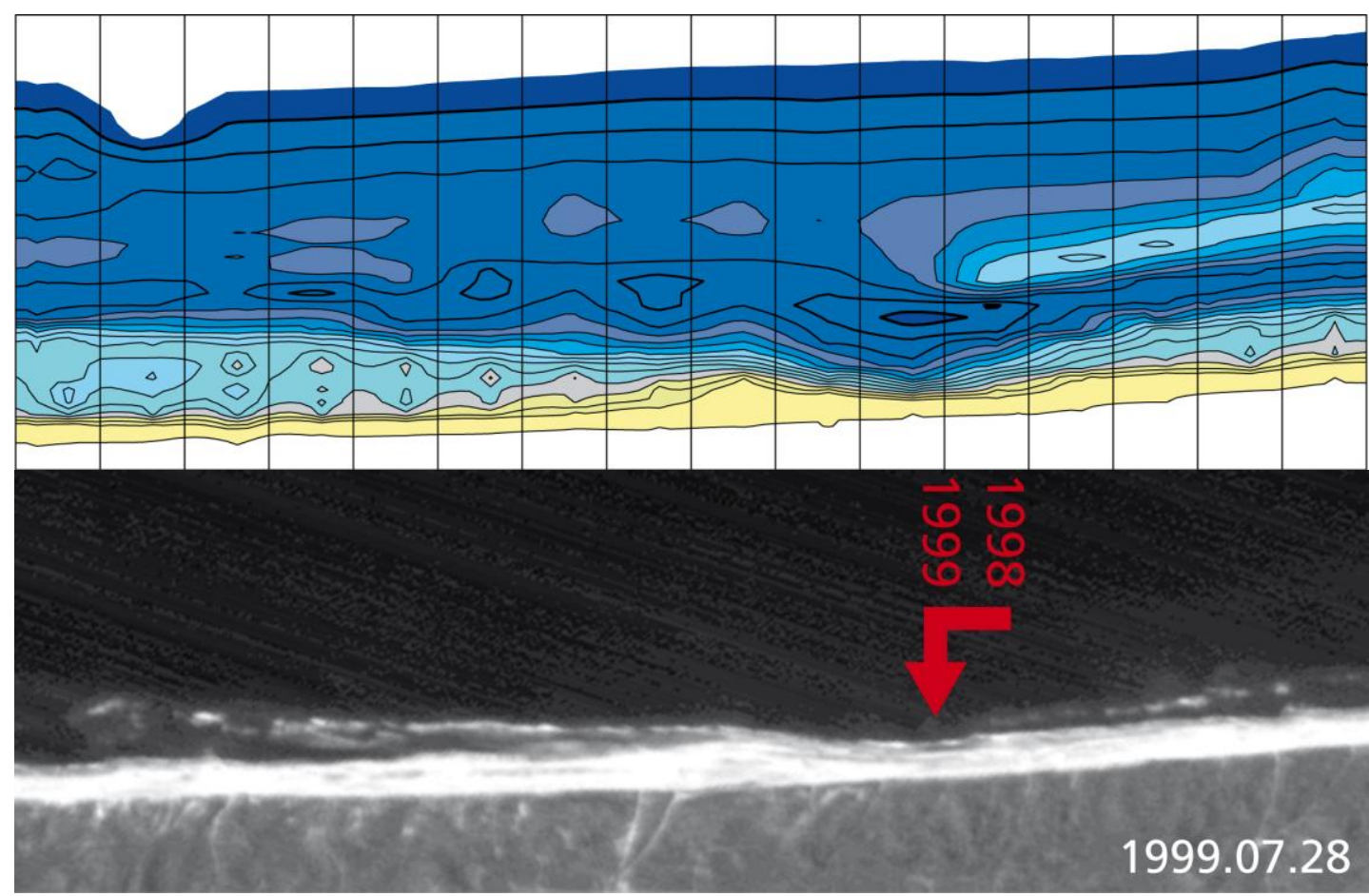

Figure 8. The coloured bathymetry and the satellite photo used to determine the position of the inward coastline undulation. 


\section{Analysis of dune retreat levels during the three storms}

All the dune front positions are related to a reference line. The line was arrived at by averaging the profiles from $+1 \mathrm{~m}$ to $-8 \mathrm{~m}$ for each transect.

Fig. 9 shows dune front positions before and after the 15 year storm in January 2000. In the figure the position of the inward coastline undulation is shown with an arrow.

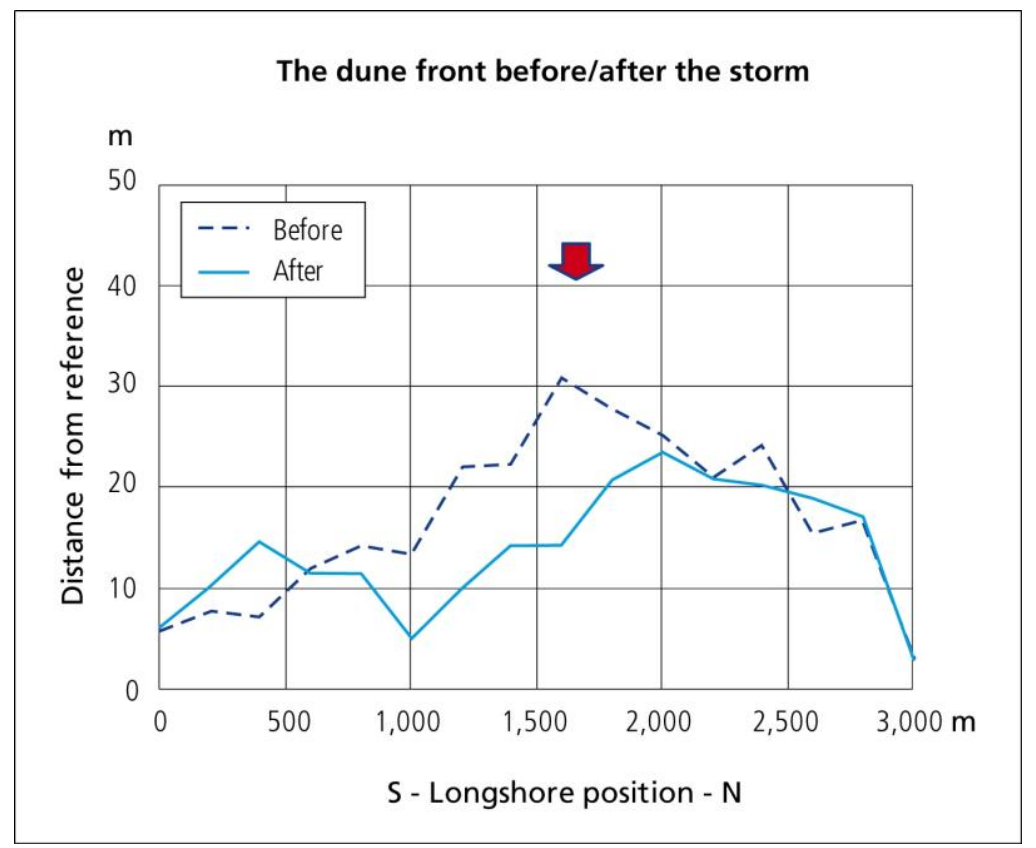

Figure 9. The 15 year storm in January 2000. Dune erosion and the position of the inward coastline undulation.

At $1600 \mathrm{~m}$ the dune front is in an advanced position, meaning that there is a risk of dune erosion. This latent erosion coincides with the inward coastline undulation and the result is about $15 \mathrm{~m}$ of dune erosion over a $1 \mathrm{~km}$ stretch.

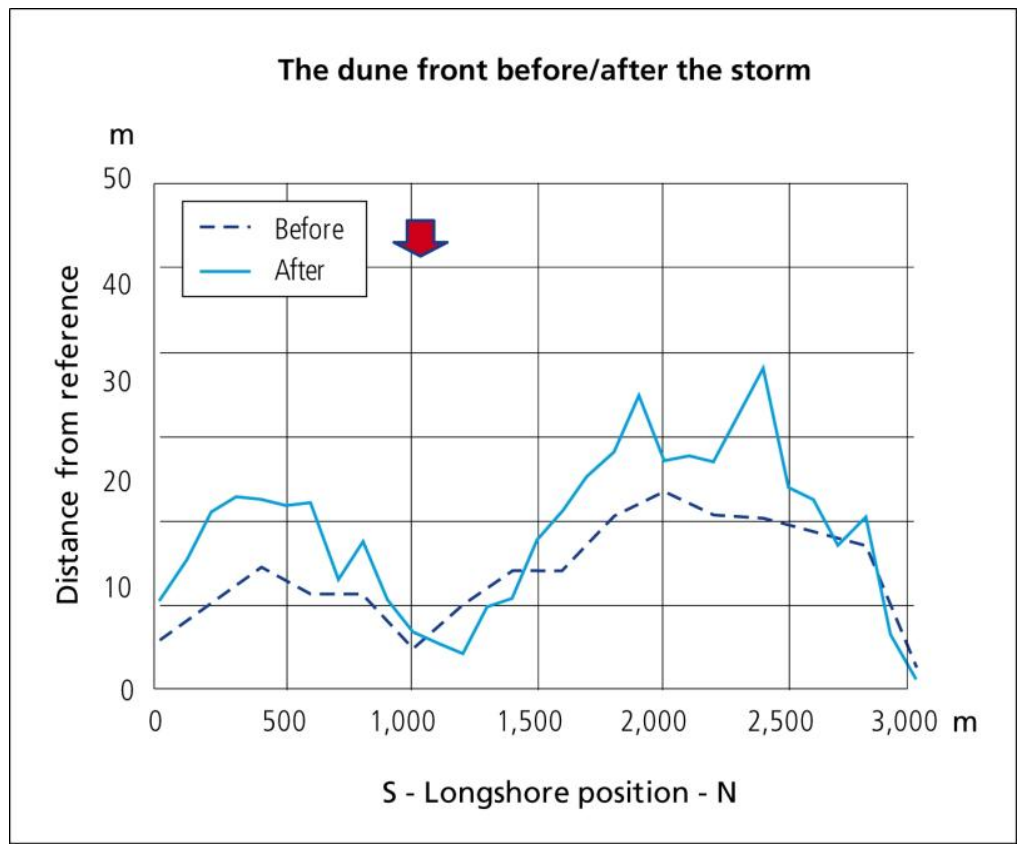

Figure 10. The 9 year storm in January 2002. Dune erosion and the position of the inward coastline undulation. 
Fig. 10 shows the dune before and after the 9 year storm in January 2002. Little dune erosion is evident although the water level was nearly the same as in the first storm. The explanation for this difference being that the inward coastline is located where there is no latent dune erosion.

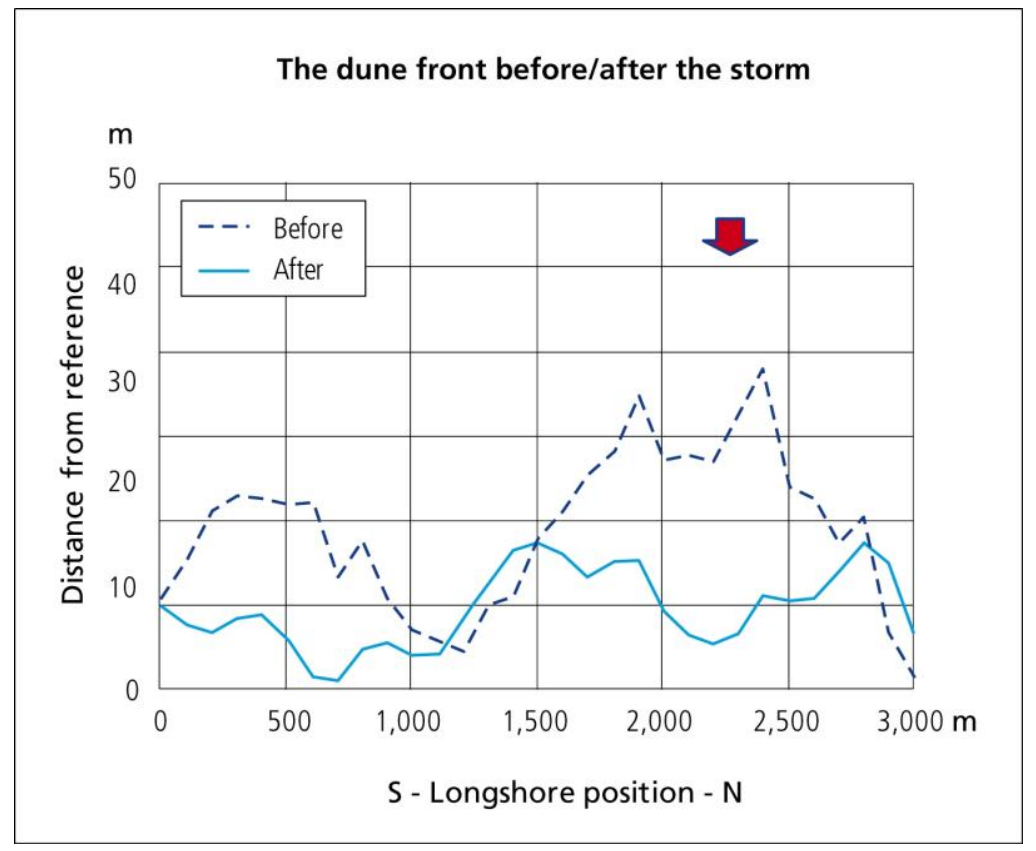

Figure 11. The 100 year storm in January 2005. Dune erosion and the position of the inward coastline undulation.

Fig. 11 shows dune erosion during the 100 year storm in January 2005. Where the latent dune erosion and the inward coastline undulation coincide dune erosion rates reach more than $20 \mathrm{~m}$ over a $1300 \mathrm{~m}$ stretch. To the south erosion levels of $12 \mathrm{~m}$ were experienced. The inward coastline undulation is not located here, but with a water level with a 100 year return period the latent erosion is sufficient to precipitate significant dune erosion. It should be noted that there are two short stretches without erosion. In these areas there is neither latent erosion nor an inward coastline undulation.

\section{Results}

The main conclusion to be drawn from the Husby case is that the combination of latent erosion and an inward coastline undulation leads to severe dune erosion if a storm hits the coast, both if it is a 100 year storm or a more moderate storm. If only latent erosion is present a tempest-level storm will cause considerable dune erosion.

\section{CONSEQUENCES OF THE REULTS FOR ANNUAL NOURISHMENT PLANNING}

The Soendervig and Husby cases indicate that local dune erosion of the magnitude of $10-25 \mathrm{~m}$ is related to a combination of latent dune erosion and an inward coastline undulation. Therefore, the Coastal Authority has decided to include an analysis of the risk of such a combination occurring in the detailed nourishment programme plan for the coming year.

Latent dune erosion will be analysed on the basis of the available surveys of coastal profiles. Generally the available data is from annual survey transects about $1 \mathrm{~km}$ apart. At a few sections of the coast there are more detailed surveys available, and where this is the case this data will be included in the analysis.

Coastline undulations will be analysed on the basis of annual satellite photos of the coast. The photos will be stored in a GIS system with the coastline undulations marked and compared to earlier positions.

If an inward coastline undulation is expected in 1-2 years time at a position where there is latent dune erosion beach nourishment will be prioritised at this section of the coast with a sand volume of $100-150 \mathrm{~m}^{3}$ per $\mathrm{m}$ coast. 
The nourishment programme for the $110 \mathrm{~km}$ long central section of the Danish North Sea coast can thus be summarised as follows:

- At the sections of the coast with revetment all nourishment will be shoreface nourishment.

- At sections without revetment most nourishment will also be shoreface nourishment. However, if an inward coastline undulation is set to coincide with latent dune erosion beach nourishment of $100-150 \mathrm{~m}^{3} / \mathrm{m}$ will take place.

\section{SUMMARY}

On the central section of the Danish North Sea coast the general coastline management strategy is to halt coastal retreat and maintain a certain safety level against flooding. This objective will mainly be fulfilled by the use of nourishment.

At the coast, large-scale local dune erosion of the magnitude of 10-25 $\mathrm{m}$ is occasionally seen even during moderate storms with return periods of 10 years. This is clearly a threat to the high water barrier but is also difficult to explain to the general public, who expect everything to be under control.

For many years the Coastal Authority has conducted research into migrating sand bars at the sea bottom. This research has included analysis of the coastline undulations and their influence on dune erosion. The two cases presented in this article, from Soendervig and Husby respectively, indicate that a combination of an inward coastline undulation and latent or unreleased dune erosion may explain sudden large-scale dune erosion.

As a consequence, the Coastal Authority has decided to include an analysis of the risk of this combination of factors arising in the annual detailed planning of the nourishment programme. If there is such a risk, beach nourishment is prioritized. It is our expectation that this new practice will reduce the scale of unforeseen dune erosion.

\section{ACKNOWLEDGMENTS}

This work has been supported by the Danish Council for Strategic Research (DSF) under the project Danish Coasts and Climate Adaptation - flooding risk and coastal protection (COADAPT), project no. 09-066869.

\section{REFERENCES}

Knudsen, S. Bjerre, H. Toxvig Madsen, and P. Soerensen. 2007. Prediction of dune erosion through monitoring of coastline undulations, Proceedings of $30^{\text {th }}$ International Conference on Coastal Engineering, ASCE, 2792-2804.

Laustrup, C., H. Toxvig Madsen, P. Soerensen, and I. Broeker. 1997. Comparison of beach and shoreface nourishment - Torsminde Tange, Denmark, Proceedings of $25^{\text {th }}$ International Conference on Coastal Engineering, ASCE, 2927-2940. 